\title{
Caddoan Archeological and Historical Workshop for the Caddo Tribe of Oklahoma in Support of Their Native American Graves Protection and Repatriation Act Grant
}

Timothy K. Perttula

Heritage Research Center, Stephen F. Austin State University

Follow this and additional works at: https://scholarworks.sfasu.edu/ita

Part of the American Material Culture Commons, Archaeological Anthropology Commons, Environmental Studies Commons, Other American Studies Commons, Other Arts and Humanities Commons, Other History of Art, Architecture, and Archaeology Commons, and the United States History Commons

Tell us how this article helped you.

This Article is brought to you for free and open access by the Center for Regional Heritage Research at SFA ScholarWorks. It has been accepted for inclusion in Index of Texas Archaeology: Open Access Gray Literature from the Lone Star State by an authorized editor of SFA ScholarWorks. For more information, please contact cdsscholarworks@sfasu.edu. 


\section{Caddoan Archeological and Historical Workshop for the Caddo Tribe of Oklahoma in Support of Their Native American Graves Protection and Repatriation Act Grant}

Creative Commons License

\section{(c) (i) (9)}

This work is licensed under a Creative Commons Attribution-NonCommercial 4.0 International License 


\title{
CADDOAN ARCHEOLOGICAL AND HISTORICAL WORKSHOP FOR THE CADDO TRIBE OF OKLAHOMA IN SUPPORT OF THEIR NATIVE AMERICAN GRAVES PROTECTION AND REPATRIATION ACT GRANT
}

\author{
Timothy K. Perttula, \\ Texas Historical Commission
}

\begin{abstract}
As part of the Native American Graves Protection Act (NAGPRA) grant recently received by the Caddo Indian Tribe of Oklahoma (Carter 1994), the Caddo Tribe of Oklahoma requested that a professional archeologist (Timothy $\mathrm{K}$. Pertula) conduct an ambitious three-day handson archeological and historical training session for tribal members, particularly members of the Caddo Repatriation Committee, in February 1995. The focus of the training session is to familiarize members of the Caddo Tribe in the identification of Caddo material culture (ceramics and lithics, as well as other types of artifacts found on habitation sites and in burial contexts), in learning the locations and distributions of prehistoric Caddo sites within the Caddoan Archeological Area, and establishing an understanding of the known locations of historic Caddo sites from archeological, historical, and archival sources.
\end{abstract}

I have been involved in Caddoan archeological and historical research for about 20 years, and completed a Ph.D. dissertation on Caddoan archeology in 1989 (Perttula 1989). I have also worked with members of the Caddo Tribe on various archeological projects in Texas, most recently as part of the Caddo Lake Scholarship program established by the Caddo Lake Institute.

To guide the training session, a compendium of basic Caddo archeological, historical, archival, and documentary records, and source materials will be compiled into a workbook for easy reference by Caddo Tribe members. Included in the workbook will be representative copies of artifact photographs and figures from each Caddo subarea (Perttula 1992:Figure 1) that illustrate the tremendous regional and temporal diversity in Caddoan material culture (in ceramics, stone, bone, shell, wood, copper, basketry, etc.) as documented in ca. A.D. 700-1800 archeological collections from Northeast Texas, Southwest Arkansas, Southeast Oklahoma, and Northwest Louisiana -- the Caddo heartland.

We also propose to bring to the training session Caddoan archeological collections from several sites that are currently being studied. This will provide an opportunity for Caddo tribal members to have hands-on experience with the more common archeological specimens typically recovered in Caddo habitation contexts (i.e., pottery sherds, stone and bone tools, etc.), and help lay out the process of establishing tribal recognition of Caddoan archeological material culture.

The more significant historical and archival sources will also be assembled in the workbook for the training session. Some of the types of documents and source materials included will consist of specific items from colonial French, Spanish, and American primary documents and 
archives (such as the Bexar Archives and the National Archives), seventeenth to nineteenth century maps, and General Land Office land survey records and field notes that reference the Caddo tribe. Also to be assembled for the training session are published documentary sources (e.g., the American State Papers, Texas Indian papers, Robertson Colony papers, Austin papers), the 1803-1814 letters and documents of John Sibley, French and Spanish expedition diaries and reports (cf. Bolton 1915), and guides to archives and manuscript sources.

Through the study of archeology, ethnohistory, and history, a great deal has been learned about the native history of the Caddo peoples. We have learned from the Caddo peoples themselves about their cultural heritage (Newkumet and Meredith 1988; Carter 1995), and professional archeologists and historians alike have finally come to appreciate that Caddo peoples today have a strong and abiding interest in retaining, preserving, and enhancing their cultural heritage.

Great opportunities exist today for archeologists, ethnohistorians, historians, and Caddo peoples to work closely together to better understand the long- and short-term course of Caddo native history. The interaction and consultation between professional archeologists and the Caddo Tribe through the NAGPRA process will allow much sharing of knowledge, and hopefully will result in new learning by both the archeological community and Caddo tribal members.

\section{BIBLIOGRAPHIC SOURCES ON CADDO ARCHAEOLOGY AND HISTORY}

Bolton, Herbert E.

1914 Anathase de Mezieres and the Louisiana-Texas Frontier, 1768-1708, 2 Volumes. Clark Publishing, Cleveland.

Brasseaux, Carl A., and Glenn R. Conrad 1992 A Bibliography of Scholarly Literature on Colonial Louisiana and New France. Center for Louisiana Studies, University of Southwestern Louisiana, Lafayette.

Brown, James A.

1971 Pottery Vessels. Spiro Studies 3. University of Oklahoma Research Institute, Norman.

\section{Carter, Mary Cecile}

1994 Presentation for "Consulting and Documenting: Practical Applications II" session at NAGPRA Compliance Workshop, Museum of Texas Tech University, Lubbock. November $1,1994$.
1995 Caddo History: Where We Come From. University of Oklahoma Press, Norman (in press).

Early, Ann M. (editor)

1993 Caddoan Saltmakers in the Ouachita Valley: The Hardman Site. Arkansas Archeological Survey, Research Series 43. Fayetteville.

Flores, Dan L.

1984 Jefferson and Southwestern Exploration: The Freeman and Custis Accounts of the Red River Expedition of 1806. University of Oklahoma Press, Noman.

Gregory, Hiram F.

1973 Eighteenth-Century Caddoan Archaeology: A Study in Models and Interpretation. Ph.D. dissertation, Southern Methodist University, Dallas. 
Harrington, Mark R.

1920 Certain Caddo Sites in Arkansas. Museum of the American Indian, Indian Notes and Monographs, Miscellaneous Series 10. New York.

Jeter, Marvin D., Jerome C. Rose, G. Ishmael Williams, Jr., and Anna M. Harmon

1989 Archeology and Bioarcheology of the Lower Mississippi Valley and Trans-Mississippi South in Arkansas and Louisiana. Arkansas Archeological Survey, Research Series 37. Fayetteville.

Kidder, T.R.

1990 The Ouachita Indians of Louisiana: An Ethnohistorical and Archaeological Investigation. Louisiana Archaeology 12:179201.

Kinnaird; Lawrence 1949 Spain in the Mississippi Valley, 1765-1794, 3 volumes. American Historical Association, Annual Report for the Year 1945. Washington D.C.

Kniffen, Fred B., Hiram F. Gregory, and G.A. Stokes

1987 The Historic Indian Tribes of Louisiana from 1542 to the Present. Louisiana State University Press, Baton Rouge.

Moore, Clarence B.

1912 Some Aboriginal Sites on Red River. Journal of the Academy of Natural Sciences of Philadelphia 14:481-644.

Neighbours, Kenneth F.

1973 Indian Exodus: Texas Indian Affairs, 1835-1859. Nortex Offset Publications, Quanah.

Neuman, Robert W. 1984 An Introduction to Louisiana Archae ology. Louisiana State University Press, Baton Rouge.
Newell, H. Perry, and Alex D. Krieger 1949 The George C. Davis Site, Cherokee County, Texas. Society for American Archaeology, Memoir 5.

Newkumet, Virginia B., and Howard L. Meredith

1988 Hasinai: A Traditional History of the Caddo Confederacy. Texas A\&M University Press, College Station.

Perttula, Timothy K.

1989 Contact and Interaction between Caddoan and European Peoples: The Historic Archaeological and Ethnohistorical Records. $\mathrm{Ph}$.D. dissertation, University of Washington, Seattle.

1992 "The Caddo Nation": Archaeological and Ethnohistoric Perspectives. University of Texas Press, Austin.

1993 Effects of European Contact on Native and Immigrant Indians in Northeast Texas. In Archeology in the Eastern Planning Region, Texas: A Planning Document, edited by Nancy A. Kenmotsu and Timothy K. Perttula. Texas Historical Commission, Department of Antiquities Protection, Cultural Resource Management Report 3:147-187. Austin.

Phillips, Philip, and James A. Brown 1978-1984 Pre-Columbian Shell Engravings from the Craig Mound at Spiro, 6 volumes. Peabody Museum Press, Cambridge.

Schambach, Frank F.

1993 Some New Interpretations of Spiroan Culture History. In Archaeology of Eastern North America: Papers in Honor of Stephen Williams, edited by James B. Stoltman. Mississippi Department of Archives and History, Archaeological Report 25:187230. Jackson. 
Shafer, Harry J.

1973 Lithic Technology at the George C. Davis Site, Cherokee County, Texas. Ph.D. dissertation, University of Texas, Austin.

Smith, F. Todd

1994 The Red River Caddos: A Historical Overview to 1835. Bulletin of the Texas Archaeological Society 65:115-127.

Story, Dee Ann et al.

1990 The Archeology and Bioarcheology of the Gulf Coastal Plain. Arkansas Archeological Survey, Research Series 38.

Story, Dee Ann (editor) 1982 The DeShazo Site, Nacodoches County, Texas, Volume 1. Texas Antiquities Committee, Antiquities Permit Series 7. Austin.

Suhm, Dee Ann, and Edward B. Jelks 1962 Handbook of Texas Archeology: Type Descriptions. Texas Archeological Society, Special Publication 1. San Antonio.

Suhm, Dee Ann, Alex D. Krieger, and Edward B. Jelks

1954 An Introductory Handbook of Texas Archeology. Texas Archeological Society Bulletin 25

Swanton, John R.

1942 Source Material on the History and Ethnology of the Caddo Indians. Smithsonian Institution, Bureau of American Ethnology, Bulletin 132. Washington D.C.

Tanner, Helen $\mathrm{H}$.

1974 The Territory of the Caddo Tribe of Oklahoma. In Caddoan Indians, Volume 4, pp. 9-144. Garland Publishing, New York.

Trubowitz, Neal L. (editor)

1984 Cedar Grove: An Interdisciplinary Investigation of a Late Caddo Farmstead in the Red River Valley. Arkansas Archeological Survey, Research Series 23. Fayetteville.
Webb, Clarence $\mathrm{H}$.

1959 The Belcher Mound: A Stratified Caddoan Site in Caddo Parish, Louisiana. Society for American Archaeology Memoir 16.

Wedel, Mildred M.

1978 LaHarpe's 1719 Post on the Red River and Nearby Caddo Settlements. Texas Memorial Museum Bulletin 30. Austin.

Winfrey, Dorman H., and James M. Day (editors)

1966 The Indian Papers of Texas and the Southwest, 1825-1916, 5 volumes. Pemberton Press, Austin.

Wyckoff, Don G.

1967 The Archaeological Sequence in the Broken Bow Reservoir Area, McCurtain County, Oklahoma. Stovall Museum of Natural History, University of Oklahoma, Norman.

1980 Caddoan Adaptive Strategies in the Arkansas Basin, Eastern Oklahoma. Ph.D. dissertation, Washington State University, Pullman.

Young, Gloria A., and Michael P. Hoffman (editors)

1993 The Expedition of Hernando de Soto West of the Mississippi, 1541-1542: Proceedings of the de Soto Symposia 1988 and 1990. University of Arkansas Press, Fayetteville. 